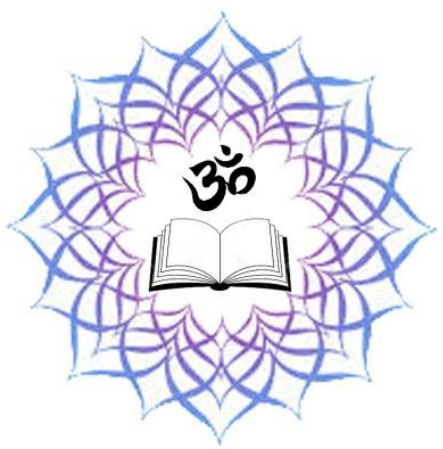

\title{
SANJIWANI JURNAL FILSAFAT
} INSTITUT HINDU DHARMA NEGERI DENPASAR Volume 11 Nomor 1, Maret 2020

\section{PLURALISME AJARAN AGAMA PADA MASA KERAJAAN BALI KUNA}

\author{
Ni Gusti Ayu Agung Nerawati
}

\section{Institut Hindu Dharma Negeri Denpasar}

\begin{tabular}{|c|c|}
\hline Keywords: & ABSTRACT \\
\hline $\begin{array}{l}\text { Pluralism, Religious } \\
\text { teachings, Ancient Balinese } \\
\text { Kingdom }\end{array}$ & $\begin{array}{l}\text { During the Ancient Kingdom in Bali, religious } \\
\text { teachings flourished well. Some sects had developed } \\
\text { during that time before finally assimilated by MPU } \\
\text { Kuturan. Some relics indicate the existence of these sects } \\
\text { which can be seen in Pusering Jagat Temple and Kebo } \\
\text { Edan Temple in Pejeng Gianyar region. At that time, the } \\
\text { sects developed well. However, in the course of time, their } \\
\text { leaders began to scramble to divide followers. This raises } \\
\text { concerns that initiative to unite among them needs to be } \\
\text { done. In order to maintain its continuity, the union is } \\
\text { considered necessary, but by still taking the main points of } \\
\text { each teaching. This is what causes Hinduism in Bali to } \\
\text { look different. When it comes to plurality, Hinduism is the } \\
\text { container, because in it the fusion of several teachings } \\
\text { which initially contradicted, but which can be adapted } \\
\text { slowly. This plurality becomes very important because, in } \\
\text { essence humans are different from one another. This } \\
\text { difference raises a different perspective. By } \\
\text { accommodating all the elements, finally everyone feels } \\
\text { accommodated. This is the message of pluralism in the era } \\
\text { of Ancient Bali. }\end{array}$ \\
\hline
\end{tabular}

\section{PENDAHULUAN}

Pengaruh Hindu bukan saja mengantarkan bangsa Indonesia memasuki zaman sejarah tetapi juga membawa perubahan dalam susunan masyarakat, yaitu timbulnya raja dan bentuk pemerintahan kerajaan, serta adanya bentuk keagamaan yang baru yaitu agama Hindu dan Buddha. Bagaimana halnya dengan keadaan di Bali? Berdasarkan keterangan beberapa prasasti kemungkinan nama Banten adalah 
nama lain dari Bali pada zaman dahulu. Prasasti Kapal abad ke-12 dikeluarkan oleh raja Paduka Sri Maharaja Sri Jayasakti menyebutkan nama desa banten. Dalam prasasti Petapan Langgaran (Kintamani) tahun 1337 menyebutkan kata banten dalam hubungan dengan nama seorang raja yaitu "Padhuka Bhatara Sri Astasura Ratna Bhumi Banten".

Menurut Dr. R. Goris, raja ini adalah raja terakhir yang memerintah karena 6 tahun kemudian Bali dikalahkan oleh Gajah Mada. Kata banten sama dengan wali yang berarti upacara seperti pujawali, pancawalikrama dan lain-lain. Dari kata wali kemudian menjadi Bali (sesuai dengan hukum bunyi dalam bahasa Indonesia). Bagaimana mengenai sistem pemerintahan di Bali pada masa lampau? Untuk mengetahui sistem pemerintahan Bali pada masa lampau para peneliti sedikit mengalami kesukaran dalam meneliti karena tidak semua raja yang pernah memerintah di Bali meninggalkan keterangan-keterangan mengenai sistem pemerintahan pada saat itu, hanya beberapa Raja meninggalkan sedikit keterangan tertulis yang juga meninggalkan gambaran umum mengenai sistem pemerintahan zaman itu, seperti pada zaman pemerintahan Raja Udayana, Jayapangus, Jayasakti dan Anak Wungsu.

Terkait dengan tujuh unsur kebudayaan menurut Koentjaraningrat yang salah satunya adalah sistem religi atau kepercayaan manusia. Dalam bidang Religi pengaruh jaman prasejarah masih terasa kuat. Kepercayaan pada jaman itu dititikberatkan pada pemujaan roh nenek moyang. Pada zaman Hindu hal itu terlihat pada bangunan pura yang mirip dengan bangunan punden berundak. Kepercayaan kepada dewa-dewa gunung, laut dal lain-lainnya tetap tercermin di dalam kehidupan masyarakat pada jaman setelah masuknya agama Hindu. Bahkan peninggalan- peninggalan sejarah itu masih disimpan dan dipuja bersama-sama dengan patung-patung Siwa dan Budha. Sistem religi di Bali khususnya di daerah Pejeng atau Bedulu yang tidak lepas dari Sejarah Kerajaan Bedahulu atau Bedulu.

Pada masa Kerajaan Bedahulu sistem religi Bali Kuna pada permulaan abad ke-8 masih dapat dibedakan antara Agama Buddha dan Hindu. Bagaimana sistem kepercayaan/Religi di Pura kebo Edan dan Pusering Jagat di mana sebagai pusat Kerajaan di Bali? Dari peninggalan-peninggalan yang terdapat di pura Kebo Edan 
Dan Pura Pusering Jagat menujukkan adanya pluralisme kepercayaan yaitu dibuktikan dengan adanya berbagai peninggalan yang menunjukkan bahwa di pura tersebut tidak hanya menganut satu kepercayaan tetapi lebih dari satu. Seperti di pura Pusering Jagat terdapat berbagai Arca antara lain Arca Ganesa, Arca Durga, serta Arca Bhairawa selain itu juga terdapat pelinggih sebagai pemujaan Ratu Purus. Dari penemuan tersebut diketahui bahwa Pura tersebut memiliki dua paham kepercayaan utama yaitu Siwa dan Bhairawa Tantra.

\section{PEMBAHASAN}

Perkembangan sistem religi yang ada di Bali, juga nampaknya dapat dijadikan acuan adanya toleransi masyarakat Bali terhadap masuknya ajaran tersebut, yang pada pembahasan sebelumnya kami sebut dengan Toleransi Ajaran dengan Institusi. Pemujaan asli masyarakat Bali masa lalu tetap diakomodir, walaupun pengaruh ajaran baru masuk, yang notabene memiliki perbedaan baik secara konsep maupun prakteknya. Hal tersebut dapat kita lihat dari adanya sistem pemujaan leluhur, yang sudah dilakukan oleh nenek moyang kita melalui media pemujaan seperti menhir dan punden berundak. Namun jika kita berusaha untuk memahami lebih jauh, ternyata terdapat kesamaan visi antara konsep ajaran Hindu dengan kepercayaan asli nenek moyang Bali. Masyarakat Bali meyakini bahwa Gunung adalah tempat suci, tempat bersemayamnya para dewa, masyarakat Bali telah mengenal pemujaan kepada matahari, api, laut, dan juga penggunaan daging, daun dan bunga dalam ritual pemujaan mereka kala itu. Konsep itu memiliki kesamaan dengan ajaran agama Hindu, yaitu memandang Gunung sebagai tempat suci karena dalam kitab Sivapurana disebutkan bahwa Gunung disebut sebagai sebuah lingga tempat pemujaan yang disebut dengan Linggaphala, matahari dipercaya sebagai perwujudan Dewa Siwa yang menjadi sumber kekuatan dan energi bagi dunia dan segala isinya sehingga disebut sebagai Siwa Raditya, dan penggunaan bunga, daun, buah dalam upakara disebutkan dalam Bhagawadgitha sebagai unsur utama pemujaan kepada Tuhan. Sedangkan penggunaan daging, darah, dan api merupakan kebiasaan leluhur sebagai sarana menolak bala, dan pada ajaran agama 
Hindu kita kenal sebagai Bhuta Yadnya/ Yadnya Bali, yang dipengaruhi oleh aliran Bhairawa khususnya aliran Tantrayana.

Adanya kesamaan visi dalam melakukan aktivitas religi antara masyarakat Bali Pra-Hindu dengan Ajaran Agama Hindu menyebabkan masuknya agama Hindu ke Bali dapat diterima masyarakat dengan baik, dan tanpa ada paksaan. Ajaran agama Hindu masuk dengan damai, dan mudah diterima dan dihayati oleh masyarakat. Akan tetapi, dari segi pengetahuan dan pemknaan terhadap aktivitas religi yang dilakukan masyarakat Bali masih kurang, hingga yang seolah-olah menjadi inti adalah aktivitas religinya bukan sumber ajarannya. Akan tetapi, bagi kalangan tertentu pendalaman ajaran menjadi suatu skala prioritas utama, sehingga pusat aktivitas religi mereka bukan pada ritual semata melainkan proses belajar tentang ilmu ke-Tuhanan tersebut. Hal itu dikarenakan, terbatasnya sumber yang dimiliki, serta tidak semua rakyat melek aksara sehingga ilmu itupun diturunkan secara rahasia dan pada kalangan tertentu dengan tujuan untuk menjaga keagungan dan kesucian ilmu tersebut. Maka dari itu banyaklah kasus kita jumpai, di masyarakat tidak tahu dan tidak memahami apa yang mereka haturkan tetapi dengan ikhlas mereka melaksanakannya.

Hal tersebut tidak saja hanya terjadi pada aktivitas ritual saja, melainkan ketidakpahaman itu juga terjadi pada infrastruktur sistem religi yang ada di Bali, dalam hal ini adalah Pura. Istilah Pura sendiri baru dikenal beberapa abad berikutnya, karena pada awalnya tempat pemujaan di Bali disebut Ulon, menurut Prasasti Sukawana dan Prasasti Pura Kehen, istilah tempat suci tersebut Ulon yang berarti berada di hulu/kepala sehingga letaknya sangat dimuliakan dan dijunjung tinggi. Selanjutnya Ulon disbut juga Hyang dan lama-kelamaan disebut dengan Kahyangan yang bermakna tempat atau stana dari Hyang/ para Dewa. Istilah Kahyangan ini masih kita jumpai hingga saat ini, khususnya bagi pura-pura tua dan pura-pura peninggalan Kerajaan Bali Kuna. Pada pemerintahan Dalem di Bali barulah istilah Hyang tersebut berubah menjadi Pura yang merujuk pada bahasa Sansekerta Pur yang berarti benteng, sedangkan tempat kediaman raja/Dalem itu sendiri disebut dengan Puri. 
Pura yang merupakan bagunan suci sebagai infrastruktur religi masyarakat Hindu di Bali, memiliki fungsi dan kegunaan yang sangat strategis dalam rangka sebagai pusat spiritual masyarakat. Berdasarkan konsep tersebut dapat kita pahami bahwasanya Pura itu memiliki peran yang kompleks yakni sosio-ekonomi-politisreligius, yang menunjukkan Pura memiliki peranan penting dalam kehidupan sosial, ekonomi, politik dan religius. Pura digunakan sebagai pemersatu rakyat, sehingga masyarakat dari status sosial dan ekonomi yang berbeda bisa disatukan dalam pura ini. Pura juga berfungsi dalam memutar roda ekonomi kerakyatan, karena dalam suatu upacara tentunya akan diperlukan bahan-bahan baku yang bersumber dari hasil lahan peranian penduduk, sehingga memungkinkan Pura menjadi roda penggerak ekonomi masyarakat. Pura juga memiliki fungsi politis yakni sebagai peredam tensi-tensi politik yang meninggi pada saat jaman kerajaan berlangsung. Hal itu diperkuat dengan adanya bukti-bukti yang berupa atefak yang berada di Pura, di mana untuk menjaga kestabilan politik dan pemerintahan, raja harus mengakomodir kepentingan rakyat, yag notabene memiiki keyakinan dan aliran kepercayaan yang berbeda, dalam hal ini adalah adanya perbedaan sekte. Seluruh fungsi di atas didasari konsep religiusitas, sehingga memungkinkan hal tersebut terjadi di Pura.

Hal yang menjadi dasar yang mengindikasikan adanya pluralisme ajaran di Pura Kebo Edan dan Pura Pusering Jagat tersebut adalah:

1. Bentuk dan langgam arca atau bangunan menunjukkan perpaduan dengan beberapa gaya arca.

2. Diketemukannya arca-arca sebagai wujud media pemujaan, yang mencirikan keanekaragaman aliran keagamaan.

3. Adanya bukti sejarah tentang pernah adanya sekte-sekte aliran keagamaan yang beragam di wilayah tersebut.

4. Adanya perbedaan cara dan teknik pemujaan yang dilakukan pada media pemujaan tersebut, walaupun ada di dalam satu areal Pura.

5. Adanya multifungsi yang dimiliki Pura, sehingga tidak spesifik untuk satu hal khusus.

Berdasarkan indikator tersebut, bahwa di Pura Kebo Edan dan Pura Pusering Jagat menunjukkan adanya suatu pluralisme ajaran keagamaan. Peninggalan arkeologis yang ada di Pura Kebo Edan dan Pura Pusering Jagat menunjukkan langgam/ style yang unik dan berbeda dari langgam arca yang ada di Bali pada 
umumnya. Sebagai contoh pada Pura Kebo Edan langgam arca yang ada di sana menunjukkan perpaduan gaya kerajaan Kediri, Singosari, dan juga ada gaya Kerajaan Bali Kuna. Bentuk arca Kerajaan Bali Kuna ditunjukkan pada arca-arca penjaga yang ada di pura, dan langgam arca Siwa Bhairawa, dan arca-arca praktek Tantra yang ada di Pura Kebo Edan menunjukkan gaya Kediri-an dan Singasari. Adapun ciri yang mengindikasikan adalah adanya ukiran-ukiran yang rumit, naturalis, dan menggunakan ukiran-ukiran yang banyak mencirikan gambargambar alam seperti, sulur-sulur dan bunga-bungaan. Pengaruh kerajaan Singosari yang ditunjukkan pada arca tersebut ditunjukkan pula pada bentuk-bentuk arca yang menunjukkan adanya praktek Tantrayana, dan juga bentuk-bentuk pemujaan kepada Sakti, yang mana kala itu di Kerajaan Singosari menganut paham Bhairawa dengan praktek Tantrayana tersebut. Sedangkan dari aliran Siwa kita dapat lihat dari adanya arca Nandhi / lembu suci wahana Dewa Siwa, adanya ornamen-ornamen Siwa Shiddhanta seperti Acintya / Sang Hyang Licin, sebagai perwujudan Paramasiwa, adanya arca Ganesha dan Lingga juga menunjukkan adanya pluralisme ajaran di Pura Kebo Edan ini.

Jika kita amati di Pura Kebo Edan ini menunjukkan pernah berkembangnya aliran Bhairawa Bima dengan praktek ajaran Tantrayana yang ditunjukkan pada bentuk-bentuk arca seperti yang dijelaskan di atas, sekte Ganesha yang ditunjukkan dengan adanya banyak ditemukannya arca Ganesha, sekte Pasupata ditunjukkan dengan adanya media pemujaan berupa lingga, sekte Siwa ditunjukkan dengan pemujaan pada dewa Siwa serta ditunjukkan denganornamen-ornamen ke-Siwa-an, sekte Bayu ditunjukkan dengan adanya pelinggih Bhatara Bayu, dan sekte Sora yang ditunjukkan dengan adanya pelinggih pemujaan kepada Dewa Surya. Berdasakan tinggalan arkeologis tersebut, dapat kita lihat bahwa indikator pluralisme yang kami sebutkan di atas tadi mutlak nyata ditunjukkan di Pura Kebo Edan ini. Namun, pada hakekatnya semua sekte di atas merupakan bagian dari ajaran Siwaisme, hanya saja media dan cara pemujaan saja yang membedakannya. Menurut Siwa Purana disebutkan bahwa dewa Siwa memiliki dua aspek yaitu Siwa sebagai Ugra dan Siwa sebagai Santa. Ketika Siwa sebagai Ugra maka digambarkan Dewa Siwa sedang krodha (kearahan) karena adanya pemusatan energi yang luar biasa, dalam rangka 
mengalahkan musuh-musuh yang menggaggu ketentraman alam semesta. Pemujaan Siwa dalam wujud ugra inilah yang digambarkan sebagai Bhairawa, Bayu, Pasupata, dan pemujaan Dewa Siwa dalam wujud santa (gembira) digambarkan sebagai Siwa Guru, Maheswara, Surya, dan lain sebagainya. Maka dari itulah kami spesifikan pembahasan kami pada bentuk pluralisme pada ajaran Siwaisme (Siwa sebagai Santa) dan ajaran Tantrayana (Siwa sebagai Ugra dalam hal ini adalah Bhairawa).

Berdasarkan penuturan dari pemangku Pura Kebo Edan, disebutkan bahwa dahulunya pura ini terletak di ujung desa Bedahulu, sehingga suasananya sepi dan menimbulkan kesan mistis. Selain itu, letak pura yang diapit oleh sungai-sungai besar, dan wilayah hutan, menyebabkan Pura Kebo Edan ini dijadikan sebagai pura penolak bahaya, untuk menjaga desa dari gangguan makhluk gaib dan bencana alam. Maka dari itulah, wajar saja di Pura ini banyak ditemukan arca Ganesha sebagai dewa wighna-gna yaitu pembasmi apa yang akan mengganggu (Nurkancana, 1998:136). Selain itu, Dewa ganesa juga dipandang sebagai dewa ulun desa yaitu Beliau yang berstana di ujung batas desa sebagai cikal bakal desa (Sedyawati, Edi, 2012: 222). Adanya sebutan lokal yang diberikan kepada manifestasi Tuhan Siwa dalam wujud arca Siwa Bhairawa yaitu Jero Balian, menunjukkan bahwa pura ini digunakan untuk memohon kesembuhan atas berbagai macam penyakkit, baik yang menimpa manusia maupun hewan ternak dan pertanian. Berdasarkan penjelasan dari Bapak Dalem selaku arkeolog memberikan pernyataan bahwa arca-rca yang ada di Pura Kebo Edan tersebut merupakan arca-arca eksitu yaitu arca yang didapatkan dari tempat-tempat yang berbeda dan kemudian dikumpulkan disatu tempat yaitu di pura ini. Suatu hal yang logis, karena pada zaman dahulu sektesekte tersebut mungkin saja melakukan pemujaan di tempat-tempat yang berbeda, apalagi sekte Bhairawa dengan Tantrayana-nya tentu saja memilih tempat yang sunyi dan angker. Akan tetapi karena kondisi masyarakat kala itu yang sudah menganut paham Siwa Siddhanta dan adanya penyatuan sekte-sekte di Bali oleh Mpu Rajakerta / Mpu Kuturan maka praktek pemujaan sekte tersebut dihentikan, dan mungkin dari sanalah baru dikumpulkan arca-arca tersebut dalam satu areal pura. Kemungkinan logis lainnya, karena mungkin ditempat itu dipandang angker 
dan penuh bahaya maka seluruh arca yang dipercaya memiliki kekuatan menolak marabahaya seperti Ganesha, Siwa Bhairawa, dan arca raksasa tersebut dikumpulkan disatu tempat dengan harapan arca tersebut dapat menurunkan kekutan Tuhan ke dunia untuk menolak marabahaya dan petaka.

Berdasarkan pernyataan-pernyataan di atas, maka kami dapat menyimpulkan bahwa pluralisme yang ada di Pura Kebo Edan memiliki motivasi spiritual tertentu yang ada kaitannya pada suatu kepercayaan masyarakat untuk memadukan kekuatan Tuhan dalam satu area pemujaan. Motivasi spiritual yang didukung dengan adanya sugesti spiritual dan pemahaman spiritual tersebut, mendukung pernyataan kami bahwa Pura Kebo Edan merupakan suatu areal pemujaan yang menunjukkan suatu toleransi dan kesatuan tujuan untuk memuja kebesaran Tuhan (Siwa) dalam berbagai aspeknya, tanpa membedakan sekte dan cara pemujaannya.

Sedangkan keberadaan Pura Pusering Jagat, bentuk pluralisme yang ditunjukkan tidak kasat mata kita temui seperti di Pura Kebo Edan, akan tetapi pluralisme yang ditunjukkan pada Pura Pusering Jagat ini lebih pada tataran konsep. Berdasarkan arti kata dari nama pura ini adalah Pura Pusering Jagat dan Pusering Tasik bermakna pusat dunia dan pusat dari samudera. Berdasarkan nama tersebut dapat kita ketahui bahwa Pura ini merupakan Pura Kerajaan Bali Kuna yang dijadikan sebagai pusat spiritual dan keagamaan masyarakat dan kerajaan masa lalu. Hal ini dapat kita amati dari kompleksitas bangunan suci yang ada di Pura ini sebagai tempat pemujaan kebesaran Tuhan dalam berbagai aspek dan manifestasi Beliau. Peninggalan sejarah yang ada di Pura ini juga membuktikan bahwa Pura ini sebagai pura Kerajaan yang dijadikan sebagai pusat aktivitas spiritual, yaitu ditampakkan dalam beragamnya bentuk arca dari berbagai zaman dan sekte yang mengindikasikan adanya suatu pluralisme di Pura ini. Sebagai Pura Pusat Kerajaan, tentunya sekte-sekte yang berkembang tersebut disatukan /digabungkan dalam satu areal pemujaan sebagai bentuk pengakomodiran negara terhadap rakyat dan kepercayaannya, serta sebagai bentuk persatuan dari warga negara dan kelompok kepercayaan spiritual tersebut pada negara. Konsep itulah yang mendasari mengapa di Pura ini sangat penting dijadikan objek studi adanya toleransi yang sangat tinggi terhadap pluralisme yang ada di masyarakat saat itu. 
Bentuk pluralisme yang dapat kita temui di Pura ini adalah adanya peninggalan-peninggalan sejarah yang mencirikan suatu sekte. Ditemukannya empat Arca Ganesha dengan berbagai ukuran dan bhawa (atribut) yang dikenakan menunjukkan pengaruh sekte Ganesha di pura ini cukup tinggi. Arca Pancuran/ Angga Tirta dan Sangku Sudamala menunjukkan bahwa di pura ini adalah memungkinkan sekte Waisnawa untuk melakukan peribatannya, di mana pada sekte Waisnawa ini sendiri sarana pemujaannya melalui sarana air sebagai simbol Dewa Wisnu yang memberika kesuburan dan memelihara alam semesta beserta isinya. Dua buah Arca Caturkaya yaitu arca yang memiliki empat buah wajah dalam satu wujud atau di kenal dengan Catur Muka, menunjukkan berkembangnya sekte Brahma, karena pengarcaan dari Dewa Brahma sendiri adalah sebagai seorang dewa yang berwajah empat. Pemujaan dengan lingga dan yoni menunjukkan berkembangnya sekte Pasupata, bahkan perwujudan lingga dan yoni itu sangat fulgar, yaitu diwujudkan langsung berupa phalus (alat kelamin laki-laki) dan vulva (alat kelamin wanita) yang memiliki makna sebagai penghormatan kepada Purusa dan Pradana agar dapat bersatu sehingga dapat memberikan kesuburan dan kehidupan bagi segala makhluk yang ada di muka bumi ini. Jika kita perhatikan dari ragam ukirnya, arca ini merupakan arca primitif yaitu arca perwujudan berdasarkan kepercayaan nenek moyang asli.

Konsep monotheisme ditunjukkan dengan adanya pelinggih Padmasana sebagai stana Ida Sang Hyang Widhi Wasa dalam wujud Nirguna Brahman). Selain itu ada pula arca perwujudan leluhur, yang diwujudkan sebagai manusia yang memakai busana yang indah dan bermahkota hanya saja tidak membawa senjata melainkan membawa bunga kuncup maupun yang mekar/ sulur bunga (Gus Japa, 2008: 157). Arca-arca primitif yaitu berupa arca yang sangat sederhana, adapun bentuknya seperti manusia dalam keadaan jongkok sambil menilangkan kakinya. Arca ini diletakkan untuk mengapit arca phalus dan vulva. Keberadaan arca primitif di pura ini menunjukkan penghargaan dan penghormatan kerajaan dan masyarakat terhadap kepercayaan nenek moyang mereka di masa lalu. Adanya arca Dhurga Mahisasura Mardhini menunjukkan adanya pemujaan kepata Sakta /Sakti, di mana arca ini memiliki ukuran $33 \mathrm{~cm}$, lebar $23 \mathrm{~cm}$ dan tebal $23 \mathrm{~cm}$, digambarkan dalam 
posisi berdiri mengangkang di atas punggung seekor mahisa. Arca Penjaga dan Raksasa yang terdapat di Jaba Tengah dan Jaba Sisi Pura, berornamenkan gelang dari tengkorak dan berdiri di atas lapik tengkorak. Keberadaan Arca Durga dan Arca Penjaga menunjukkan pengaruh sekte Bhairawa Tantra masih berkembang dan dihormati di pura ini.

Berdasarkan data-data tersebut dapat kita amati bahwa di Pura Pusering JagatPusering Tasik ini merupakan wujud kongkrit dari pluralisme tersebut baik secara konsep maupun secara prakteknya. Akan tetapi hal yang harus kita garis bawahi dari konsep pluralisme ajaran di Pura ini adalah bagaimana leluhur dan para guru suci kita dahulu mengakomodir semua kepercayaan lokal dan sekte-sekte yang berkembang dahulu di Kerajaan Bali Kuna tersebut sehingga dapat hidup harmonis dan saling mendukung terwujudnya suasana kondusif di kerajaan baik secara sekala maupun niskala. Sekte dan kepercayaan tersebut kemudian dipersatukan dalam sebuah areal Pura ini, merupakan suatu bentuk saling hormat menhormati perbedaan tersebut yang sudah ditanamkan oleh leluhur orang Bali dari sejak zaman dahulu kala. Seperti pada pembahasan sebelumnya seluruh sekte-sekte yang ada tersebut pada dasarnya merupakan bersumber dari ajaran Siwaisme karena tujuan akhirnya adalah penyatuan diri kepada Siwa (Tuhan Yang Maha Esa) itu sendiri. Akan tetapi, secara umum bentuk pemujaan Siwa Siddhanta dan Bhairawa Tantra sangat mendominasi sistem religi dan praktek keagamaan masyarakat Bali Kuna saat itu. Adanya dominasi pemujaan kepada Siwa dan Bhairawa dengan jalan Tantrayana saat itu sangat mungkin terjadi karena pengaruh kerajaan KadiriSingosari (Jawa) dengan konsep Bairawa Tantra-nya cukup lama dianut oleh masyarakat Bali Kuna.

Kemudian setelah adanya keputusan Samuan Tiga tersebut barulah terjadi penyempurnaan terhadap ajaran Siwa Siddhanta di Bali, dan terus mengalami penyempurnaan hingga saat ini kita warisi. Selain alasan tersebut, kondisi masayarakat Bali Kuna yang masih serba terbatas dan dalam kondisi bahaya, maka pemujaan kepada Bhairawa sebagai sarana penolak marabahaya (tolak bala) sangat dominan dilaukan di masyarakat, guna menjaga keselamatan negara dan keamanan rakyat. Sedangkan pengaruh Siwa sendiri juga sejatinya sangat tinggi, karena 
merupakan landasan dasar dalam sistem religi yang berkembang di kerajaan Bali Kuna hingga saat ini. Maka dari itu pemujaan kepada Siwa dilakukan sangat diutamakan, yaitu dengan menstanakan Dewa siwa di Pura ini. Berdasarkan kedudukan dan fungsinya Pura ini termasuk Sad Kahyangan dan Padma Bhuana yang berada di wilayah tengah yang merupakan stana dari Dewa Siwa itu sendiri. Hal itu yang menunjukkan bahwa keberadaan Pura ini merupakan pura pemersatu pluralisme umat dalam sebuah payung spiritual yaitu Siwa Siddhanta itu sendiri.

\section{PENUTUP}

Pada masa Kerajaan Bali Kuna ketika pusat kerajaan berada di Bedahulu, kehidupan beragama di Bali di dasarkan pada ajaran yang bercorak Siwa. Selain itu berkembang pula sekte-sekte, seperti sekte Siwa dan sekte Bhairawa Tantra. Pada perkembangan selanjutnya sekte-sekte tersebut pada akhirnya bersatu berdasarkan hasil Rapat Besar Pemuka Agama di Pura Samuan Tiga, menjadi paham Tri Murti Siwa Siddhanta. Keberadaan sekte-sekte tersebut mempengaruhi sistem religi di Kerajaan Bali Kuna, dan menjadi dasar pijakan sistem religi di masa-masa berikutnya.

Pluralisme ajaran Siwaisme dan Bhairawa Tantra yang ada di Pura Kebo Edan dan Pura Pusering Jagat ditunjukkan dengan ditemukannya berbagai macam arca perwujudan dewa dari beberapa sekte yang berkembang di Kerajaan Bali Kuna. Kedua Pura tersebut memiliki arca yang bercorak Siwa Siddhanta, sekte Ganesha, Paśupata, Waisnawa, Brahma, dan Bhairawa Tantra. Keberadaan arca yang bercorak sekte-sekte yang berbeda di sebuah areal pura menunjukkan adanya suatu pluralisme dalam sistem religi namun terdapat suatu toleransi yang tinggi antara sekte yang satu dengan yang lainnya. Pluralisme yang ditunjukkan pada Pura Kebo Edan dan Pura Pusering Jagat-Pusering Tasik menunjukkan fungsi infrastruktur religi dalam suatu sistem religi pada Kerajaan Bali Kuna, dalam hal ini adalah kedua Pura tersebut berfungsi untuk membina kerukunan dan mempersatukan masyarakat. 


\section{DAFTAR PUSTAKA}

Adnyana, Gede Agus Budi. 2012. "Tutur Maharaja Bhairava". Gianyar: Gandapura.

Atmaja, I Made Nada, dkk. 2009. "Śiwa, Sadaśiwa dAan Paramaśiwa (Śiwaratri). Surabaya: Pāramita.

Darmayuda, I Made Suasthawa. 1995. “Kebudayaan Bali, pra- Hindu, masa Hindu, dan Pasca Hindu". Denpasar: Kayumas Agung.

Keramas, Dewa Made Tantera. 2008. “Metoda Penelitian Kwalitatif dalam Ilmu Agama dan Kebudayaan. Surabaya: Pāramita.

Nantra, I Ketut, dkk. 2008. "Nawa Sangga Tirthayatra". Surabaya: Pāramita.

Nurkancana, Wayan. 1997. "Menguak Tabir Perkembangan Hindu". Surabaya: Pāramita.

Soebandi, Ketut. 2007. "Pura Kawitan/ Padharman dan Penyungsungan Jagat". Denpasar: Kayumas Agung.

Soekmono. 1973. "Pengantar Sejarah Kebudayaan Indonesia". Yogyakarta : Kanisius.

Tim Penyusun. 1980. “Buku Sejarah Bali”. Denpasar: Bali Offset.

Titib, I Made. 2003. "Teologi dan Simbol-Simbol dalam Agama Hindu". Surabaya: Pāramita.

Yuniarthi, Ni Wayan. 2003. "Tantra dan Seks". Surabaya: Pāramita.

http://thearoengbinangproject.com/pura-kebo-edan-gianyar-bali/. Diakses tanggal 14 Maret 2014.

www.parisada.org/index.php?option=com_content\&task=view\&id=1251\&Itemid.

Diakses tanggal 14 Maret 2014.

Www. anneahira.com/pengertian-metode-penelitian. Diakses tanggal 12 Maret 2014 mastarmudi.blogspost./.../pengertian-observasi. Diakses tanggal 12 Maret 2014 http://pendidikan4sejarah.blogspot.com/2011/08/pura-kebo-edan.html. Diakses tanggal 14 Maret 2014.

http:/ / dewagedeekawidnyana.blogspot.com/2012/10/pura-pusering-jagat-pejenggianyar-bali/. Diakses tanggal 14 Maret 2014

agoescha.blogspost.com/20/12/03/penjelasan-bali.html?m=1. Diakses tanggal 14 Maret 2014. 